\title{
THE EFFECT OF TYPE AND DOSE OF ANTI-INFLAMMATORY DRUGS ON THE VIABILITY AND OSTEOGENIC POTENTIAL OF DENTAL PULP STEM CELLS
}

\author{
Mohamed R. Elmansy*, Menatalla M. Elhindawy** and Mohamad E. Helal ${ }^{* * *}$
}

\begin{abstract}
Objectives: The use of nonsteroidal anti-inflammatory drugs (NSAIDs) after regenerative surgeries may affect the behavior of stem cells used during the treatment. This study investigates the possible effect of NSAIDs on the proliferation and the osteo-differentiation of dental pulp stem cells (DPSCs) in vitro.
\end{abstract}

Methods : DPSCs were isolated, cultured and characterized with human antibodies CD90, CD105 and CD45. Cells were cultured for a period of 1, 3 and 5 days to assess the viability using different drug concentrations of acetylsalicylic acid (ASA) 10, 50, and $200 \mu \mathrm{g} / \mathrm{mL}$., Diclofenac sodium $10^{-4}$ and $10^{-6} \mathrm{M}$ and Meloxicam $0.01,0.1$, and $1 \mu \mathrm{M}$.Selected concentration of ASA $10 \mu \mathrm{g} /$ $\mathrm{mL}$, Diclofenac sodium $10^{-6} \mathrm{M}$ and Meloxicam $0.1 \mu \mathrm{M}$ were used during osteo-differentiation of the cells.

Results : DPSCs viability assay recorded the highest absorption rate on the $1^{\text {st }}$ day with ASA $10 \mu \mathrm{g} / \mathrm{mL}$ and on the $3^{\text {rd }}$ day with Meloxicam $0.01 \mu \mathrm{M}$. On day 5 all concentration of ASA and Diclofenac reported the highest absorption rats. The highest values of calcium compounds was expressed with ASA $10 \mu \mathrm{g} / \mathrm{mL}$ on the $7^{\text {th }}$ day using alizarin red satin.

Conclusion : Using different types of NSAIDs during the postsurgical regimen can affect the viability and osteo-differentiation of DPSCs.

KEY WORDS : Dental pulp stem cells, regenerative medicine, analgesics, viability, osteodifferentiation.

\section{INTRODUCTION}

Tissue damage after surgical intervention triggers coagulation, inflammation and then healing. The healing and regenerative capacity of tissues depend on their stem cell population, which has self-renewal capability and the ability to differentiate into specialized cells. ${ }^{1}$ Thorough out the healing process, the health care practitioner has

\footnotetext{
* Dentist, Egyptian Ministry of Health And Population, Mansoura, Egypt

** Lecturer of Oral Biology, Oral Biology Department, Faculty of Dentistry, Mansoura University, Egypt

*** Professor of Oral Biology, Oral Biology Department, Faculty of Dentistry, Mansoura University, Egypt
} 
to control the pain and inflammation postoperative, hence the use of nonsteroidal anti-inflammatory drugs (NSAIDs). ${ }^{2}$

NSAIDs are a diverse group of compounds with similar biological capabilities, pain is relived mainly by blocking cyclooxygenase-2 (COX-2) mostly in the central nervous system, but not much in the rest of the body. It can be classified as selective or nonselective COX inhibitors. ${ }^{3}$

NSAIDs became popular as a part of the pain control regimen if not the first choice in acute pain. According to research $60 \%$ of patients respond well to any NSAIDs and $40 \%$ will respond to another type NSAID. The effect of NSAIDs manifests itself very soon after the patient had consumed them and the full effect occurs within one week. ${ }^{4}$ NSAIDs are safe, well tolerated and are considered the first choice among analgesics for patients undergoing surgical procedures but they can delay or impair bone healing at certain critical stages in the healing process. $^{5}$

Dental pulp stem cells (DPSCs) are colonies of highly proliferative fibroblastic-like shaped cells with high frequency of colony-forming and a high rate of proliferation. ${ }^{5}$ They have the ability to differentiate into at least 3-cell lineages odontogenic/ osteogenic, neurogenic and adipogenic, confirming their mesenchymal identity. ${ }^{7}$

Mesenchymal stem cells (MSCs)- derived from bone marrow- have been proven to prevent the expression of pro-inflammatory cytokines such as interferon- $\gamma$ "IFN- $\gamma$ " and tumor necrosis factor- $\alpha$ "TNF- $\alpha$ " ${ }^{8}$ Cell to cell contact of MSCs with periodontal ligament fibroblast in vitro had an immunomodulatory influence on terminating the inflammatory process during healing. ${ }^{9}$ Also the use of bone marrow MSCs in treating rheumatoid arthritis proved to suppress the inflammatory cytokines. ${ }^{10}$ Transplantation of DPSCs in diabetic rats modulated the proportions of macrophages and produced abundant immunomodulatory cytokines indicating its important role in the anti-inflammatory effects of the treatment of diabetic polyneuropathy. ${ }^{11}$

Regenerative medicine and tissue engineering aim to restore structure and function of tissues and organs ${ }^{12}$ through the combined use of stem cells, bio-scaffold and growth factors. ${ }^{13}$ In the oral and maxillofacial region, bone regeneration and repair are of interest. Mandibular bone defects were repaired using collagen sponge scaffold and DPSCs harvested from the third molars of the patient. ${ }^{14}$ Stem cells with osteogenic potentials provided accelerated bone formation in large alveolar bone defects as well as enhanced osseointegration in dental implant treatments. ${ }^{15}$

Drug administration for pain relief after surgical procedures is the most controllable factor, because their impact on bone healing can accounted for depending on choice and dosage. ${ }^{5}$

Understanding the influence of different types of NSAIDs on DPSCs proliferative and osteodifferentiation potentials in vitro is important for the implantation of regenerative medicine in the oral and maxillofacial region.

\section{MATERIALS}

Chlorhexidine (Kenara mouthwash; Macro Group Pharmaceuticals)

Phosphate buffered saline (PBS, Gibco)

Dulbecco's Modified Eagle Media- Ham's F12 (DMEM/F12; Lonza

Fetal Bovine Serum (FBS) (Gibco)

Penicillin and streptomycin (Pen/Strip) (Gibco)

Trypsin EDTA (ThermoFisher SCINTIFIC)

acetylsalicylic acid (ASA) (Sodium salt powder purchased from EL Nasr Pharmaceutical Chemical Company, Cairo, Egypt)

Diclofenac sodium (Novartis Pharma AG, Basel, Switzerland)

Meloxicam (Adwia Pharmaceuticals Co., Egypt) 


\section{METHODS}

\section{Isolation of DPSCs}

DPSCs were isolated from chronic inflamed soft tissue impacted lower third molar that was indicated for extraction from young healthy patients. Patient_consent was obtained through the Ethics committee of Faculty of Dentistry, Mansoura University, Egypt. The extraction procedures were held in the Oral Surgery department, Faculty of Dentistry, Mansoura University, Egypt under severe sterilization protocol. Extracted teeth were disinfected by immersion in chlorhexidine for 2 minutes in sterile falcon tubes then were removed with a sterile tweezer to another set of sterile falcon tubes containing phosphate buffered saline

The extracted teeth were then transported in the PBS's to laminar flow hood where the teeth were crushed using a Hand Held Pulp Isolator device. The pulp tissue was excavated with small sterile excavator then minced into small fragments by two opposing scalpels moving in a cross manner.

\section{Growth of HDPSCs}

Pulp pieces were cultured in $25 \mathrm{~cm}^{2}$ flask (Greiner) with $10 \mathrm{ml}$ Dulbecco's Modified Eagle Media- Ham's F12 supplemented with 10\% Fetal Bovine Serum (FBS) and 1\% penicillin and streptomycin (Pen/Strip). The cultured pieces were then incubated at $37^{\circ} \mathrm{C}$ and $5 \% \mathrm{CO}^{2}$ atmosphere.

Complete Media (CM) (DMED/F12 + FBS + Pen/strip) was replaced every three days. The first passage was performed when monolayer of adherent cells reached 70-80 \% confluence. Feeding continued with the protocol of cell culturing until the cells reached $4^{\text {th }}$ passage when they were ready to be used. During passaging, cells were de-adhered with trypsinization process.

\section{Flow cytometry analysis of HDPSCs}

At the $4^{\text {th }}$ passage cells were characterized using cell surface antigen expressions: DPSCs were detached by $0.5 \mathrm{~mL}$ of $\% 0.25$ trypsin EDTA and washed with PBS followed by incubation with antibodies for human CD90 phycoerythrin (PE), CD105 PE and CD45 fluorescein isothiocyanate (FITC) at $4^{\circ} \mathrm{C}$ for 30 minutes. Acquisition and analysis for CD105 and CD90 were performed with a BD Accuri C6 flow cytometer and for CD 45 were done by fluorescein activated cell sorting (FACS) Canto, BD, USA) $\}$ and the data analyzed with BD Cell Quest ${ }^{\mathrm{TM}}$ Pro version C6.0 software (BD, USA).

\section{Assessment of cell viability}

DPSCs were seeded at $2.5 \times 10^{4}$ cells/well in a 96 well plate at a final volume of $100 \mu \mathrm{L}$ of $\mathrm{CM}$ and cultured overnight at $37^{\circ} \mathrm{C}$ and $5 \% \mathrm{CO}^{2}$. Following that, cells were divided into control group cultured in $\mathrm{CM}$ only and experimental groups cultured with different concentrations of ASA 10, 50, and $200 \mu \mathrm{g} / \mathrm{mL}$, Diclofenac sodium $10^{-4}$ and $10^{-6} \mathrm{M}$ and Meloxicam $0.01,0.1$, and $1 \mu \mathrm{M}$ for 1,3 and 5 days ( 3 wells for each concentration in each time period for all groups). At the end of the treatment $100 \mu \mathrm{L}$ of 3-(4, 5-dimethyl thiazol-2-yl)-5-(3carboxymethoxyphenyl)-2-(4-sulfophenyl)-2H tetrazolium inner salt (MTS; Promega) were added to the plates. Absorbance was measured at $490 \mathrm{~nm}$ with a spectrophotometer (Thermo fisher scientific, Waltham, MA, USA). (Table 1)

\section{Osteogenic differentiation assay}

To induce mineralization, DPSCs were seeded at $2 \times 10^{4}$ cells/well in the 6 well plates and treated with osteogenic differentiating media containing nutritional media (DMEM-F12), 50 $\mu \mathrm{g} / \mathrm{ml}$ of L-ascorbic acid 2-phosphate, $10 \mathrm{mM}$ of $\beta$-glycerophosphate sodium salt, $0.1 \mu \mathrm{M}$ of dexamethasone, antibiotics $(100 \mathrm{mg} / \mathrm{ml}$ streptomycin and $100 \mu / \mathrm{ml}$ Penicillin-G) and 10\% FBS. NSAIDs were added to the media with selected concentrations ASA $10 \mu \mathrm{g} / \mathrm{mL}$, Diclofenac sodium $10^{-6} \mathrm{M}$ and Meloxicam 0.1 $\mu \mathrm{M}$. The cells were maintained in osteogenic differentiation media for 7 days and the 
media renewed every 3 days. ${ }^{16}$ After the $7^{\text {th }}$ day, a quantified analysis was conducted by Alizarin redbased assay, $10 \%$ buffered formalin for 10 minutes and stained with $2 \%$ alizarin red S (Wako, Osaka, Japan) for 15 minutes at room temperature so that the mineral matrix of the bone could be observed. The intensity of calcium compound staining was evaluated by MTT assay measured with optical density at $405 \mathrm{~nm}$ (ELISA reader).

DPSCs cultured with no osteogenic medium were used as control negative group and DPSCs cultured with osteogenic medium were used as control positive group. (Table 1)

TABLE (1): Showing experimental groups.

\begin{tabular}{|c|c|c|}
\hline $\begin{array}{c}\text { Experimental } \\
\text { Groups }\end{array}$ & $\begin{array}{l}\text { Viability } \\
\text { potential }\end{array}$ & $\begin{array}{c}\text { Osteogenic } \\
\text { differentiation }\end{array}$ \\
\hline \multirow{3}{*}{ ASA Group } & $10 \mu \mathrm{g} / \mathrm{mL}$ & \multirow{3}{*}{$10 \mu \mathrm{g} / \mathrm{mL}$ group } \\
\hline & $50 \mu \mathrm{g} / \mathrm{mL}$ & \\
\hline & $200 \mu \mathrm{g} / \mathrm{mL}$ & \\
\hline \multirow{2}{*}{$\begin{array}{c}\text { Diclofenac sod. } \\
\text { Group }\end{array}$} & $10^{-4} \mathrm{M}$ & \multirow{2}{*}{$10^{-6} \mathrm{M}$ group } \\
\hline & $10^{-6} \mathrm{M}$ & \\
\hline \multirow{3}{*}{$\begin{array}{l}\text { Meloxicam } \\
\text { group }\end{array}$} & $0.01 \mu \mathrm{M}$ & \multirow{3}{*}{$0.1 \mu \mathrm{M}$} \\
\hline & $0.1 \mu \mathrm{M}$ & \\
\hline & $1 \mu \mathrm{M}$ & \\
\hline
\end{tabular}

\section{Statistical analysis}

Data were tabulated, coded then analyzed using Statistical Package for Social Science (SPSS) version 20.0. Descriptive statistics were calculated in the form of Mean \pm Standard deviation (SD). In the statistical comparison between the different groups, the significance of difference was tested using one-way ANOVA. For all tests, accepted statistical significances for probability $(\mathrm{P})$ was valued at $<0.05$.

\section{RESULTS}

\section{Cell culture}

Cultures were observed using inverted light microscope; they appeared rounded and floating on the $5^{\text {th }}$ day of isolation. Two weeks after isolation, the cells took a spindle shape and were interlaced with each other. The primary culture reached $70-80 \%$ of confluence after 3 weeks of isolation and cells were moved to the $2^{\text {nd }}$ passage by trypsinization. (Fig. 1)

\section{Flow cytometry analysis}

Surface antigen analysis for DPSCs at the $4^{\text {th }}$ passage revealed that cells were positive to CD90 (72.6 \pm 0.1$)$ and CD105 (70.06 \pm 0.19$)$ while cells expressed negative results $(10.1 \pm 0.9)$ for the hematopoietic marker (CD45). (Fig 2)

\section{Assessment of cell viability}

In the control and NSAID- treated cells, cell viability was determined by rate of absorption of MTS agent. On the $1^{\text {st }}$ day, the highest rate of absorption among ASA concentrations was recorded with $10 \mu \mathrm{g} / \mathrm{mL}(1.95 \pm 0.1)$. In Diclofenac, the highest absorption was recorded at $10^{-6}$ concentration $(2.01 \pm 0.05)$ and in_Meloxicam the highest rate was recorded was at $0.01 \mu \mathrm{M}$ concentration $(1.31 \pm 0.02)$. The highest absorption rate was recorded on the $3^{\text {rd }}$ day with Meloxicam at $0.01 \mu \mathrm{M}$ concentration (2.16 \pm 0.01$)$. The highest values in ASA $10 \mu \mathrm{g} / \mathrm{mL}$ concentration and Diclofenac $10^{-4} \mathrm{M}$ concentration were $(1.65 \pm 0.04)$ and $(1.66 \pm 0.11)$ respectively. On the $5^{\text {th }}$ day, both ASA and Diclofenac concentrations recorded higher absorption rates when compared to Meloxicam concentrations. (Table 2)_

\section{Osteogenic differentiation assay}

Mineralization capability for DPSCs treated with selected concentrations of NSAID was measured with alizarin red staining. ASA $10 \mu \mathrm{g} / \mathrm{mL}$ shows large red area with traces of minute deposits, Diclofenac sodium $10^{-6} \mathrm{M}$ shows different separated 
red deposits while Meloxicam 0.1 $\mu \mathrm{M}$ showed the least deposits. The intensity of calcium compound by MTT assay confirmed the quantified analysis by alizarin red: ASA $10 \mu \mathrm{g} / \mathrm{mL}$ showed the highest rate
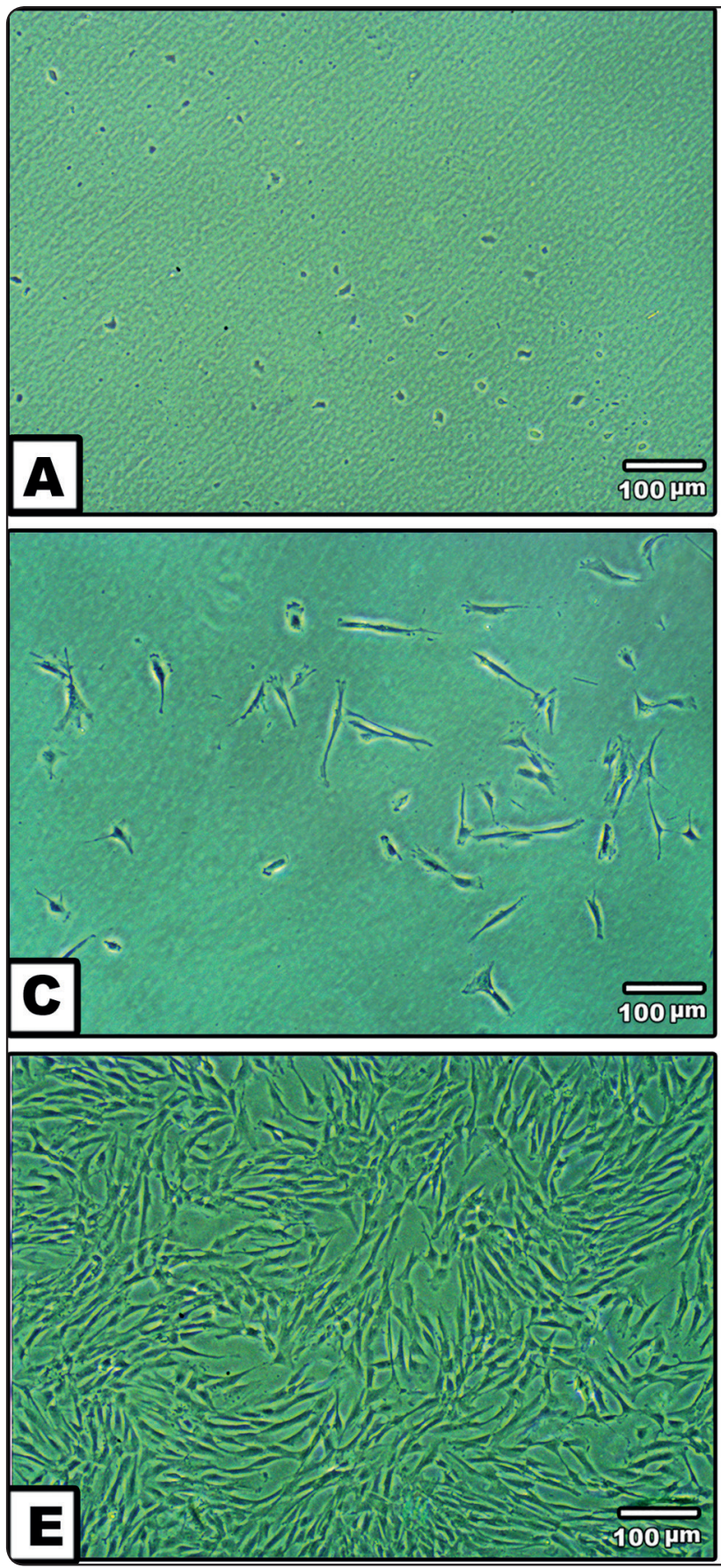

of absorption ( $0.26 \pm 0.01)$, followed by Diclofenac sodium $10^{-6} \mathrm{M}(0.18 \pm 0.08)$. The least absorption rate recorded was Meloxicam $0.1 \mu \mathrm{M}(0.13 \pm 0.01)$. (Fig 3)

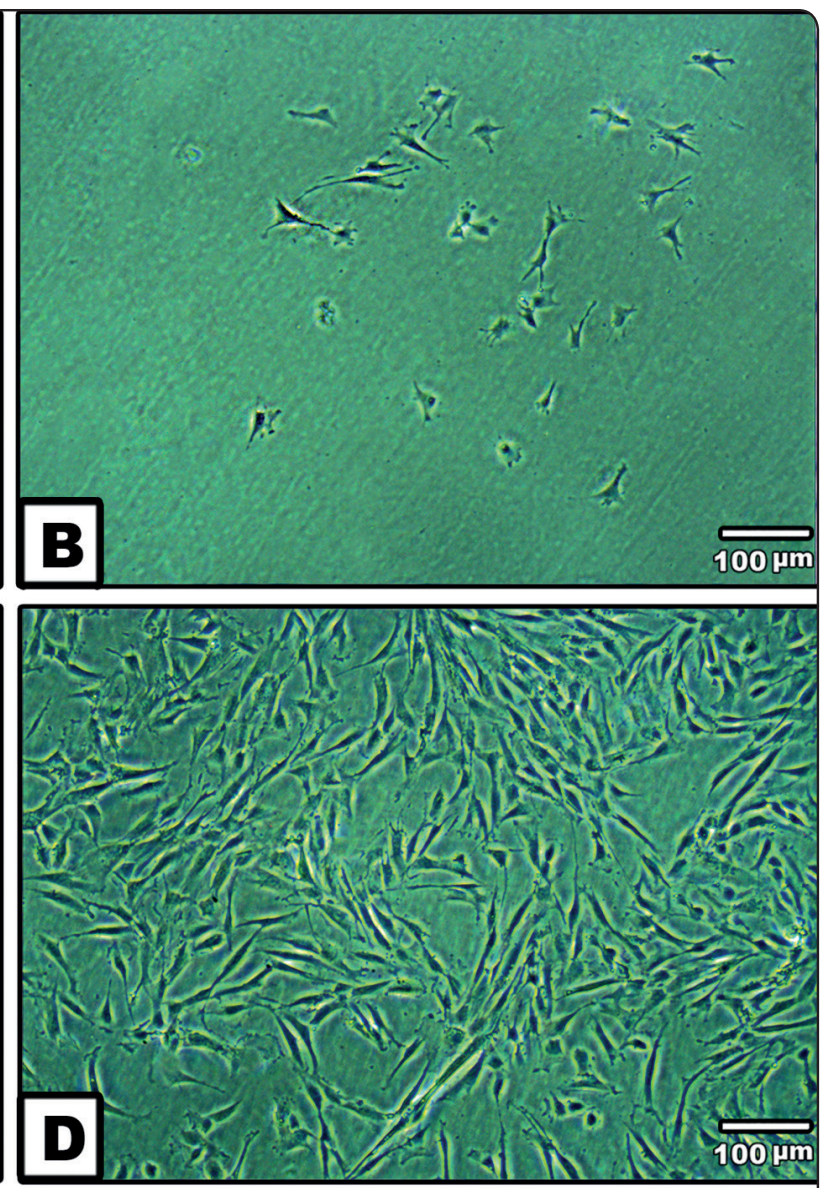

Fig. (1) Inverted light microscopic images showing DPSCs colony formation capacity A) Isolated DPSCs, B) Isolated HDPSCs after incubation for 7 days, C) after 2 weeks, D) 1 day after 1st passage and $\mathrm{E}$ ) after 3 weeks. (original magnification $\mathrm{x} 10$ ) 


\section{Statistical analysis}

One-way ANOVA for proliferation MTS assay for different concentration NSAIDs revealed that ASA $10 \mu \mathrm{g} / \mathrm{mL}$ concentration showed significant difference than the control group, $50 \mu \mathrm{g} / \mathrm{mL}$ and 200 $\mu \mathrm{g} / \mathrm{mL}$ concentration on the $1^{\text {st }}$ day. The difference was significant at $200 \mu \mathrm{g} / \mathrm{mL}$ concertation only on the $3^{\text {rd }}$ and $5^{\text {th }}$ days. ASA $50 \mu \mathrm{g} / \mathrm{mL}$ was significant to the control group on the $3^{\text {rd }}$ day and to $200 \mu \mathrm{g} /$ $\mathrm{mL}$ concentration on the $5^{\text {th }}$ day. ASA $200 \mu \mathrm{g} / \mathrm{mL}$ was significant to $10 \mu \mathrm{g} / \mathrm{mL}$ concentration at all times and to control on $3^{\text {rd }}$ and $5^{\text {th }}$ days and to 50 $\mu \mathrm{g} / \mathrm{mL}$ at the $5^{\text {th }}$ day only. Both $10^{-4} \mathrm{M}$ and $10^{-6} \mathrm{M}$ concentrations of Diclofenac showed significant difference to each other and to control group only on the $1^{\text {st }}$ day. Also $0.01 \mu \mathrm{M}, 0.1 \mu \mathrm{M}$ and $1 \mu \mathrm{M}$ concentrations of Meloxicam were significant to each other and to control group only on the $3^{\text {rd }}$ day (Table 3).

As for osteogenic differentiation, ASA $10 \mu \mathrm{g} /$ $\mathrm{mL}$ group showed a significant difference to control positive group, Meloxicam $0.1 \mu \mathrm{M}$ group and Diclofenac sodium $10^{-6} \mathrm{M}$ group. Diclofenac sodium $10^{-6} \mathrm{M}$ group revealed a significant difference to Meloxicam $0.1 \mu \mathrm{M}$ only while Meloxicam $0.1 \mu \mathrm{M}$ group showed a significant difference for control positive group (Table 4).

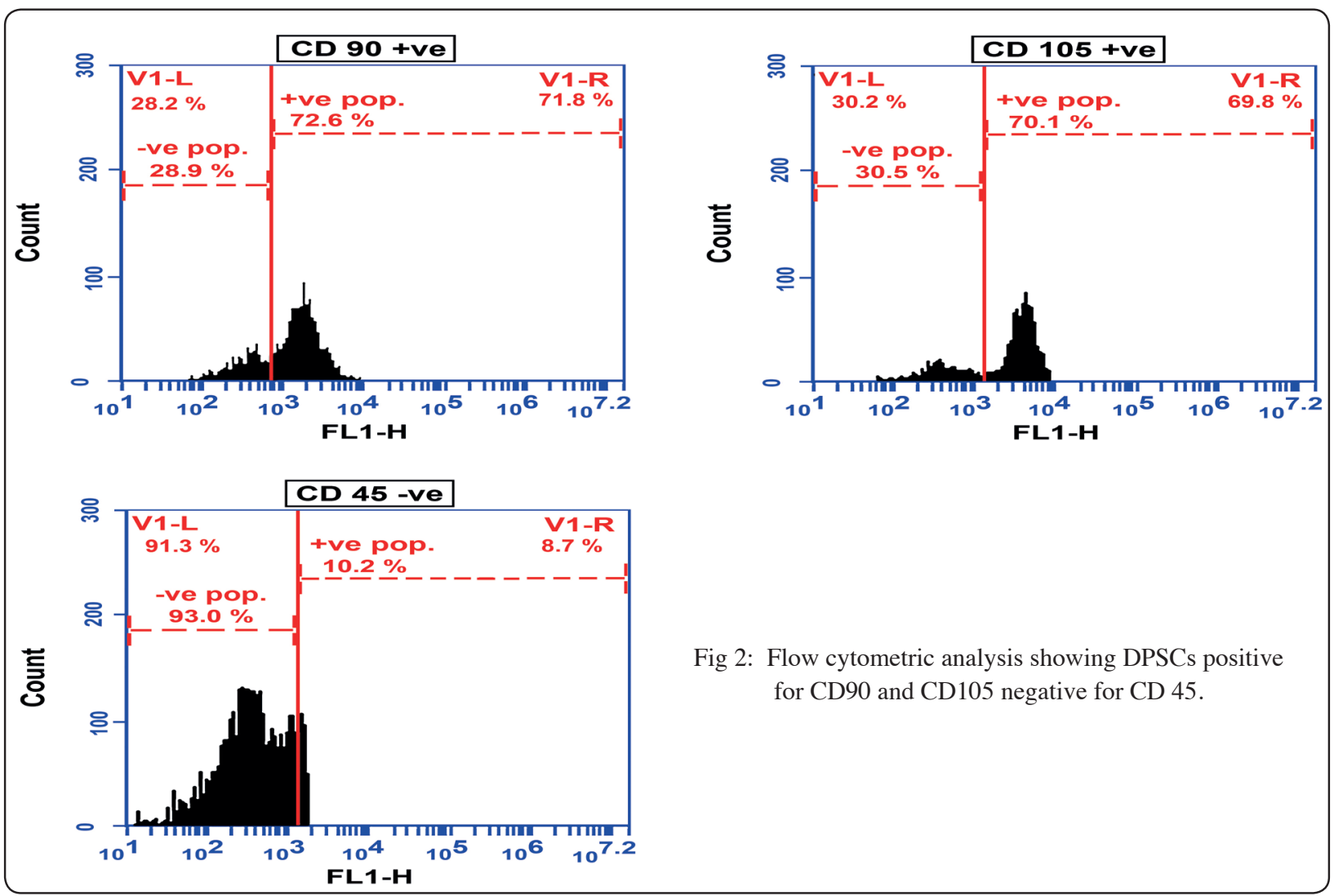



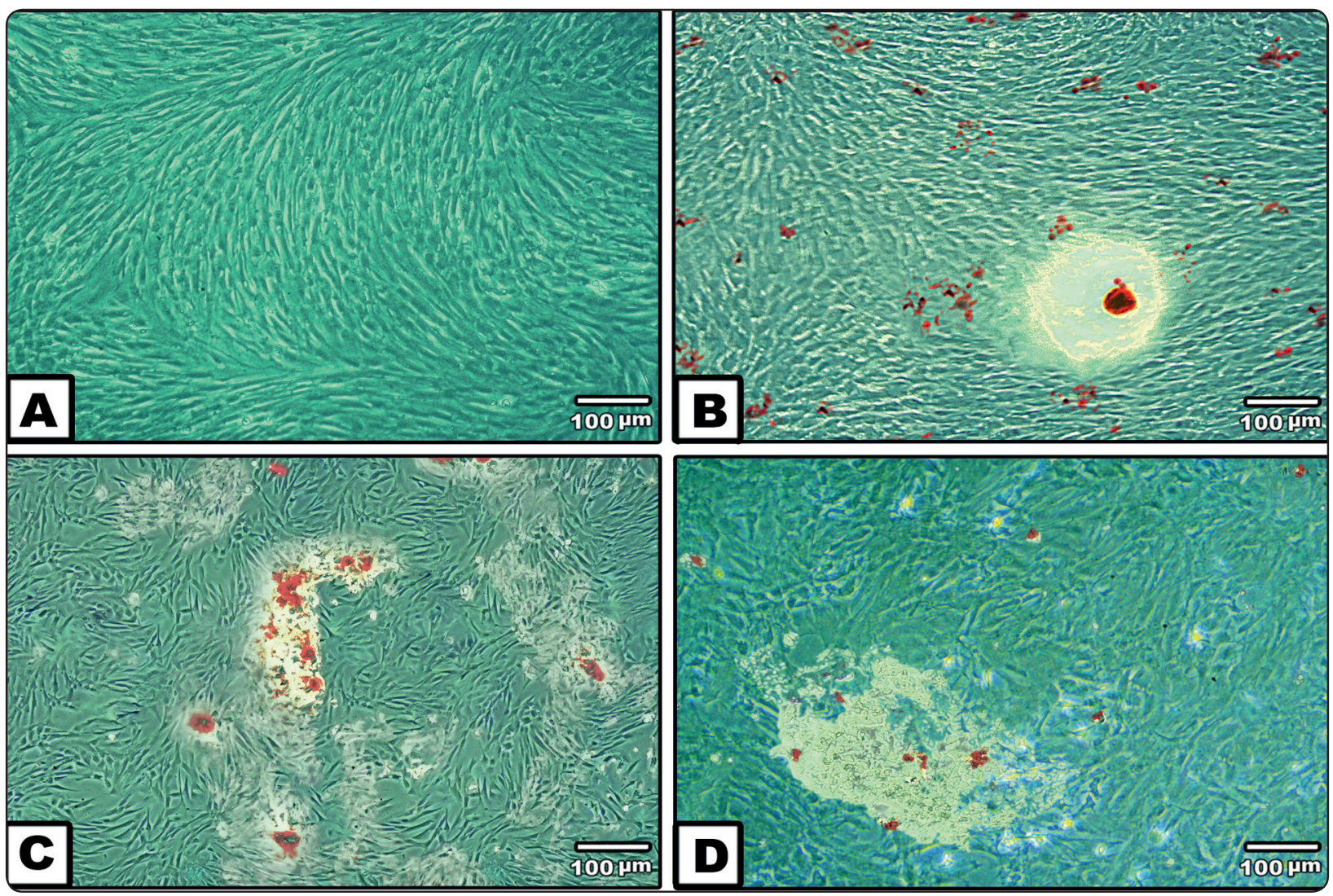

Fig 3: Inverted light microscopic images showing osteogenic capability of DPSCs after 7 days (A) control positive group, (B) ASA $10 \mu \mathrm{g} / \mathrm{mL}$, (C) Diclofenac sodium 10-6 M,(D) Meloxicam 0.1 $\mu \mathrm{M}$. (Alizarin red stain, original magnification x 10)

TABLE (2) Comparison between Control \& NSAIDs concentrations different time periods

\begin{tabular}{|c|c|c|c|c|c|c|c|}
\hline & & \multicolumn{2}{|c|}{ Day 1} & \multicolumn{2}{|c|}{ Day 3} & \multicolumn{2}{|c|}{ Day 5} \\
\hline & & Mean & $\pm \mathrm{SD}$ & Mean & $\pm \mathrm{SD}$ & Mean & $\pm \mathrm{SD}$ \\
\hline \multicolumn{2}{|c|}{ Control group } & 1.771 & 0.062 & 1.700 & 0.104 & 2.318 & 0.172 \\
\hline \multirow[t]{3}{*}{ ASA Group } & $10 \mu \mathrm{g} / \mathrm{mL}$ & 1.950 & 0.100 & 1.652 & 0.043 & 2.408 & 0.188 \\
\hline & $50 \mu \mathrm{g} / \mathrm{mL}$ & 1.778 & 0.152 & 1.582 & 0.052 & 2.463 & 0.052 \\
\hline & $200 \mu \mathrm{g} / \mathrm{mL}$ & 1.741 & 0.089 & 1.540 & 0.026 & 2.076 & 0.093 \\
\hline \multirow{2}{*}{$\begin{array}{l}\text { Diclofenac } \\
\text { sod. Group }\end{array}$} & $10^{-4} \mathrm{M}$ & 1.850 & 0.088 & 1.660 & 0.110 & 2.246 & 0.134 \\
\hline & $10^{-6} \mathrm{M}$ & 2.017 & 0.057 & 1.587 & 0.009 & 2.418 & 0.095 \\
\hline \multirow{3}{*}{$\begin{array}{c}\text { Meloxicam } \\
\text { group }\end{array}$} & $0.01 \mu \mathrm{M}$ & 1.314 & .024 & 2.167 & .011 & 1.805 & .057 \\
\hline & $0.1 \mu \mathrm{M}$ & 1.263 & .079 & 2.274 & .012 & 1.898 & .095 \\
\hline & $1 \mu \mathrm{M}$ & 1.247 & .031 & 2.378 & .044 & 1.878 & .036 \\
\hline
\end{tabular}


TABLE (3) Significant differences between all NSAIDs concentrations at different time periods

\begin{tabular}{|c|c|c|c|c|}
\hline \multicolumn{2}{|c|}{} & Day 1 & Day 3 & Day 5 \\
\hline \multirow{3}{*}{ ASA Group } & $10 \mu \mathrm{g} / \mathrm{mL}$ & $\mathrm{P} 1=0.038^{*}$ & $\mathrm{P} 1=0.56$ & $\mathrm{P} 1=0.67$ \\
\cline { 2 - 5 } & $50 \mu \mathrm{g} / \mathrm{mL}$ & $\mathrm{P} 1=0.99$ & $\mathrm{P} 1=0.02^{*}$ \\
& & $\mathrm{P} 2=0.048^{*}$ & $\mathrm{P} 2=0.25$ & $\mathrm{P} 2=0.9$ \\
\cline { 2 - 5 } & $200 \mu \mathrm{g} / \mathrm{mL}$ & $\mathrm{P} 1=0.96$, & $\mathrm{P} 1=0.001^{*}$, & $\mathrm{P} 1=0.03^{*}$, \\
& & $\mathrm{P} 2=0.01^{*}$ & $\mathrm{P} 2=0.028^{*}$ & $\mathrm{P} 3=0.002^{*}$ \\
\hline \multirow{3}{*}{ Diclofenac sod. } & $10^{-4} \mathrm{M}$ & $\mathrm{P} 3=0.93$ & $\mathrm{P} 3=0.65$ & $\mathrm{P} 1=0.13$ \\
\cline { 2 - 5 } Group & $10^{-6} \mathrm{M}$ & $\mathrm{P} 1=0.15$ & $\mathrm{P} 1=0.1$ & $\mathrm{P} 4=0.13$ \\
& & $\mathrm{P} 1=<0.001^{*}$ & $\mathrm{P} 1=0.13$ \\
\hline \multirow{2}{*}{ Meloxicam } & $0.01 \mu \mathrm{M}$ & $\mathrm{P} 4=0.003^{*}$ & $\mathrm{P} 4=0.1$ & $\mathrm{P} 1=0.11$ \\
\cline { 2 - 5 } & $0.1 \mu \mathrm{M}$ & $\mathrm{P} 1=0.3$ & $\mathrm{P} 1=0.99$ & $\mathrm{P} 1=0.11$ \\
& & $\mathrm{P} 1=0.3$ & $\mathrm{P} 1=<0.001^{*}$ & $\mathrm{P} 5=0.11$ \\
\cline { 2 - 5 } & $1 \mu \mathrm{P}$ & $\mathrm{P} 5=0.3$ & $\mathrm{P} 5=<0.001^{*}$ & $\mathrm{P} 1=0.11$, \\
& & $\mathrm{P} 1=0.3$, & $\mathrm{P} 1=<0.001^{*}$, & $\mathrm{P} 5=0.11$ \\
& & $\mathrm{P} 6=0.3$ & $\mathrm{P} 6=<0.001 *$ & 0.11 \\
\hline
\end{tabular}

P1: significance relative to Control group

P3: significance relative to ASA50

P5: significance relative to $0.01 \mu M$ Meloxicam group
P2: significance relative to ASA10

P4: significance relative to $\mathrm{DIC} 10^{-4}$ group

P6: significance relative to $0.1 \mu M$ Meloxicam group

TABLE (4) Comparison of osteogenic capability of dental pulp stem cells between different studied groups

\begin{tabular}{|c|c|c|c|c|c|c|c|c|c|c|}
\hline & \multicolumn{2}{|c|}{$\begin{array}{c}\text { Control negative } \\
\text { group }\end{array}$} & \multicolumn{2}{|c|}{$\begin{array}{c}\text { Control positive } \\
\text { group }\end{array}$} & \multicolumn{2}{|c|}{$\begin{array}{c}\text { Meloxicam } 0.1 \\
\mu \mathrm{M} \text { group }\end{array}$} & \multicolumn{2}{|c|}{$\begin{array}{c}\text { Diclofenac sodium } \\
\qquad 10^{-6} \mathrm{M} \text { group }\end{array}$} & \multicolumn{2}{|c|}{$\begin{array}{l}\text { ASA } 10 \mu \mathrm{g} / \mathrm{mL} \\
\text { group }\end{array}$} \\
\hline & Mean & $\pm \mathrm{SD}$ & Mean & $\pm \mathrm{SD}$ & Mean & $\pm \mathrm{SD}$ & Mean & $\pm \mathrm{SD}$ & Mean & $\pm \mathrm{SD}$ \\
\hline osteogenic capability & .282 & .036 & .194 & .032 & .133 & .018 & .189 & .008 & .268 & .012 \\
\hline Significance & & & \multicolumn{2}{|c|}{$\mathrm{P} 1=<0.001 *$} & \multicolumn{2}{|c|}{$\begin{array}{l}\mathrm{P} 1=<0.001 * \\
\mathrm{P} 2=0.001 *\end{array}$} & \multicolumn{2}{|c|}{$\begin{array}{c}\mathrm{P} 1=<0.001 * \\
\mathrm{P} 2=0.99 \\
\mathrm{P} 3=0.003^{*}\end{array}$} & \multicolumn{2}{|c|}{$\begin{array}{c}\mathrm{P} 1=0.8 \\
\mathrm{P} 2=<0.001 * \\
\mathrm{P} 3=<0.001 * \\
\mathrm{P} 4=<0.001 *\end{array}$} \\
\hline
\end{tabular}

P1: significance relative to Control negative group

P2: significance relative to Control Positive group

P3: significance relative to $0.1 \mu M$ Meloxicam group

P4: significance relative to $10-^{6} \mathrm{M}$ Diclofenac sodium group 


\section{DISCUSSION}

Tissue engineering is a promising solution for tissue and organ reconstruction and transplantation of newly formed bone chips obtained in vitro. The real challenge was to have DPSCs planted into a scaffold developed into well vascularized adult human bone. ${ }^{17}$

Drugs have an impact on bone healing and repair and although the choice and dosage of analgesics can be controlled, the use of NSAIDs cannot be controlled as much. NSAIDs are the most often used drugs, not only in prescription but also as selfmedication to control both pain and inflammation. ${ }^{18}$

In the current the study, DPSCs isolated from the third molar and cultured in culture media showed positive expression to surface markers CD 90 and CD 105 but negative expression to CD 45. The results were in agreement with the International Society of Cellular Therapy (ISCT) 2006 which stated that MSCs must express CD 90 and CD 105 but lack expression of CD $45 .{ }^{19}$

Our results also showed that ASA concentrations 10 and $50 \mu \mathrm{g} / \mathrm{mL}$ enhanced the proliferation of DPSCs, while a higher dose $200 \mu \mathrm{g} / \mathrm{mL}$ had no effect. Also the osteogenic capability of the DPSCs was enhanced with ASA at $10 \mu \mathrm{g} / \mathrm{mL}$ concentration. These results are in agreement with Liu et al. 2015, who found that ASA at 10-50 $\mu \mathrm{g} /$ $\mathrm{mL}$ concentrations promoted proliferation and osteogenic differentiation of stem cells derived from deciduous teeth. The researchers attributed this findings to low dose of ASA which enhanced the activity of telomerase which in extend the stem cells life span and improve their functions. ${ }^{20}$

In contrary to our results, Abd Rahman et al. 2016 stated that ASA concentrations $10 \mu \mathrm{g} / \mathrm{mL}$ to $200 \mu \mathrm{g} / \mathrm{mL}$ had an inhibitory effect on proliferation of periodontal ligament stem cells. ${ }^{21}$ Also Cao et al. 2015 reported that ASA concentrations 100 to 150 $\mu \mathrm{g} / \mathrm{mL}$ display an inhibitory effect on proliferation of swine bone marrow stem cells. ${ }^{22}$
Regarding osteogenic differentiation of periodontal ligament stem cells Abd Rahman et al. 2016 reported that ASA concentrations 10 and $200 \mu \mathrm{M}$ reduced osteogenic differentiation on days 7 due to the inhibition of growth factors as Runtrelated transcription factor 2 (RUNX2). RUNX2 upregulation causes various events that eventually lead to the expression of osteogenic proteins. ${ }^{21}$

In the present study, Diclofenac sodium at concentration $10^{-6} \mathrm{M}$ and $10^{-4}$ showed positive proliferative effect on DPSCs. Also, it promoted the oseogentic ability of DPSCs at concentration $10^{-6} \mathrm{M}$. These findings are in contradict with Chang et al.'s 2007 who stated that NSAIDs such as Diclofenac sodium suppress the proliferation but not the osteogenesis of mesenchymal stem cells at the therapeutic doses. ${ }^{23}$

Our study found that 0.1 and $1 \mu \mathrm{M}$ Meloxicam showed more cell proliferation on the $3^{\text {rd }}$ day than other time periods. The osteogenic capability of cells treated with $0.1 \mu \mathrm{M}$ Meloxicam was the lowest when compared to other NSAIDs. These results are in agreement with Muller et al. 2011 who reported that Meloxicam concentrations from 0.01 to 10 $\mu \mathrm{M}$ induced more marked increasing effects on equine mesenchymal stem cell proliferation. Also Meloxicam of $1 \mu \mathrm{M}$ concentration showed negative effects on osteogenic differentiation capability. ${ }^{16}$

Our data show that the use of therapeutic concentrations of NSAIDs have an effect on DPSCs capability of proliferation and cell growth as well as on its osteogenic differentiation. As a matter of fact, those therapeutic concentrations can be used to promote the proliferation at certain periods.

Although there is growing evidence of the antiinflammatory properties of stem cell therapy, there is no evidence on its ability to replace or reduce the use of pain killers and analgesics with antiinflammatory properties after surgical intervention. 


\section{RECOMMENDATION}

The choice of the appropriate NSAID in the intervention of a stem cell-based therapy is critically important. According to our data, shifting from one dug to another may enhance the proliferation and osteo-differentiation of the cells. The study recommends to use of Diclofenac sodium $10^{-6} \mathrm{M}$ as a potent drug of choice in the $1^{\text {st }}$ days postoperative followed by Meloxicam 0.1 $\mu \mathrm{M}$ from the $3^{\text {rd }}$ day to avoid peptic ulceration then continue the treatment with ASA $10 \mu \mathrm{g} / \mathrm{mL}$ starting from the $5^{\text {th }}$ day.

\section{ACKNOWLEDGMENT}

We would like to thank Ahmed Shetewy, Faculty of Dentistry, Mansoura University for his device "Hand Held Pulp Isolator". We also would like to thank Medical Experimental Research Center of Mansoura University (MERC) for their continuous support.

\section{REFERENCES}

1. Ledesma-Martínez E, Mendoza-Núñez VM, Santiago-Osorio E. Mesenchymal stem cells derived from dental pulp: A review. Stem Cells Int. 2016;2016. doi:10.1155/2016/4709572

2. White PF, Tang J, Wender RH, et al. The effects of oral ibuprofen and celecoxib in preventing pain, improving recovery outcomes and patient satisfaction after ambulatory surgery. Anesth Analg. 2011;112(2):323-329. doi:10.1213/ ANE.0b013e3182025a8a

3. Jahnavi K, Pavani Reddy P, Vasudha B, Narender B, Nonsteroidal anti-inflammatory drugs: an overview, Journal of Drug Delivery and Therapeutics. 2019; 9(1-s):442-448. http://dx.doi.org/10.22270/jddt.v9i1-s.2287

4. Bailey E, Patel N, Coulthard P. Non-steroidal anti-inflammatory drugs for pain after oral surgery. Oral Surg. 2014;7(3):152-161. doi:10.1111/ors.12073

5. Lisowska B, Kosson D, Domaracka K. Positives and negatives of nonsteroidal anti-inflammatory drugs in bone healing: The effects of these drugs on bone repair. Drug Des Devel Ther. 2018;12:1809-1814. doi:10.2147/DDDT. S164565
6. Gronthos S, Mankani M, Brahim J, Robey PG, Shi S. Postnatal human dental pulp stem cells (DPSCs) in vitro and invivo. Proc Natl Acad Sci. 2000;97(25):13625-13630. doi:10.1073/pnas. 240309797

7. Huang GTJ, Gronthos S, Shi S. Critical reviews in oral biology \& medicine: Mesenchymal stem cells derived from dental tissues vs. those from other sources: Their biology and role in Regenerative Medicine. J Dent Res. 2009;88(9):792-806. doi:10.1177/0022034509340867

8. Iyer SS, Rojas M. Anti-infl ammatory effects of mesenchymal stem cells : novel. Published online 2008:569-582.

9. Suzuki K, Chosa N, Sawada S, Takizawa N, Yaegashi T, Ishisaki A. Enhancement of Anti-Inflammatory and Osteogenic Abilities of Mesenchymal Stem Cells via Cell-to-Cell Adhesion to Periodontal LigamentDerived Fibroblasts. Stem Cells Int. 2017;2017:1-12. doi: $10.1155 / 2017 / 3296498$

10. F HAA, F ASA. Anti-inflammatory and antioxidant effects of mesenchymal and hematopoietic stem cells in a rheumatoid arthritis rat model. Published online 2018. doi: $10.17219 /$ acem/73720

11. Omi M, Hata M, Nakamura N, et al. Transplantation of dental pulp stem cells suppressed in $\mathrm{fl}$ ammation in sciatic nerves by promoting macrophage polarization towards anti-in fl ammation phenotypes and ameliorated diabetic polyneuropathy. 2016;7(4):485-496. doi:10.1111/ jdi. 12452

12. Mason C, Dunnill P. A brief definition of regenerative medicine. Regen Med. 2008;3(1):1-5. doi:10.2217/17460751.3.1.1

13. Rodríguez-Lozano FJ, Insausti CL, Iniesta F, et al. Mesenchymal dental stem cells in regenerative dentistry. Med Oral Patol Oral Cir Bucal. 2012;17(6):1062-1067. doi: $10.4317 /$ medoral.17925

14. d'Aquino R, De Rosa A, Lanza V, et al. Human mandible bone defect repair by the grafting of dental pulp stem/progenitor cells and collagen sponge biocomplexes. Eur Cells Mater. 2016;18:75-83. doi:10.22203/ecm.v018a07

15. Sunil P, Manikandhan R, Muthu M, Abraham S. Stem cell therapy in oral and maxillofacial region: An overview. J Oral Maxillofac Pathol. 2012;16(1):58. doi:10.4103/0973029X.92975

16. Müller M, Raabe O, Addicks K, Wenisch S, Arnhold S. Effects of non-steroidal anti-inflammatory drugs on proliferation, differentiation and migration in equine 
mesenchymal stem cells. Cell Biol Int. 2011;35(3):235248. doi:10.1042/cbi20090211

17. D’Aquino R, Papaccio G, Laino G, Graziano A. Dental pulp stem cells: A promising tool for bone regeneration. Stem Cell Rev. 2008;4(1):21-26. doi:10.1007/s12015-008-9013-5

18. F.P.B. K, L.R.A. van der B, S. R, et al. Non-steroidal anti-inflammatory drugs (NSAIDs) for axial spondyloarthritis (ankylosing spondylitis and non-radiographic axial spondyloarthritis). Cochrane Database Syst Rev. 2015;2015(7):CD010952. doi:http://dx.doi.org/10.1002/14651858.CD010952.pub2

19. Dominici M, Le Blanc K, Mueller I, et al. Minimal criteria for defining multipotent mesenchymal stromal cells. The International Society for Cellular Therapy position statement. Cytotherapy. 2006;8(4):315-317. doi:10.1080/14653240600855905

20. Liu Y, Chen C, Liu S, et al. Acetylsalicylic acid treatment improves differentiation and immunomodu- lation of SHED. J Dent Res. 2015;94(1):209-218. doi: $10.1177 / 0022034514557672$

21. Abd Rahman F, Mohd Ali J, Abdullah M, Abu Kasim NH, Musa S. Aspirin Enhances Osteogenic Potential of Periodontal Ligament Stem Cells (PDLSCs) and Modulates the Expression Profile of Growth Factor-Associated Genes in PDLSCs. J Periodontol. 2016;87(7):837-847. doi:10.1902/ jop. 2016.150610

22. Cao Y, Xiong J, Mei S, et al. Aspirin promotes bone marrow mesenchymal stem cell-based calvarial bone regeneration in mini swine. Stem Cell Res Ther. 2015;6(1):1-11. doi:10.1186/s13287-015-0200-4

23. Chang JK, Li CJ, Wu SC, et al. Effects of anti-inflammatory drugs on proliferation, cytotoxicity and osteogenesis in bone marrow mesenchymal stem cells. Biochem Pharmacol. 2007;74(9):1371-1382. doi:10.1016/j. bcp.2007.06.047 